\title{
The impact of uptake of selected agricultural technologies on rice farmers' income distribution in Ghana
}

\author{
Monica Addison ${ }^{{ }^{*}}$ (D) Kwasi Ohene-Yankyera² ${ }^{2}$ Patricia Pinamang Acheampong ${ }^{3}$ and \\ Camillus Abawiera Wongnaa²
}

\begin{abstract}
Background: Government of Ghana's effort to reduce income inequality consistently poses a major challenge to public policy formulation. The promotion and dissemination of agricultural technologies as a pathway out of income inequality in rural Ghana have received widespread support. Yet, knowledge about the impact of agricultural technologies on rural income inequality remains low. The objective of the study is to evaluate the link between the uptake of improved rice technologies and income distribution in the study area.
\end{abstract}

Methods: This paper uses a survey data from 917 smallholder rice producers in selected communities in Ghana. The study employs the Bourguignon, Fournier, and Gurgand (BFG) selection bias correction model, a two-stage model, to empirically analyse the role of agricultural technologies in rural income distribution.

Results: The empirical result shows that education, farm size, land ownership, participation in relevant extension training programmes enhance adoption, but gender (female) inhibits uptake of the selected technologies. The empirical result further shows that the uptake of the improved rice seed and fertilizer increases rice farmers' net revenue significantly. The result further indicates that farmers' choice of the selected agricultural technologies decreases the sample population income inequality, indicating the uptake of the technologies has an equalizing effect on rice farmers' income distribution.

Conclusion: The study concludes that the use of the selected technologies has potential to fight rural poverty in Ghana. The findings have implications for National Development Planning Commission (NDPC) agenda of redistribution of wealth in Ghana.

Keywords: Agricultural technology, Food security, Income inequality, Rural Ghana, Rice farmers

JEL Codes: D31, O13, O33, O55, Q12, Q55

\section{Background}

In Ghana, the agricultural sector is an important economic sector and a key source of livelihood for the rural populace. The sector contributes significantly (19.1\%)

*Correspondence: monicaddo@yahoo.com

1 Bureau of Integrated Rural Development (BIRD), Kwame Nkrumah University of Science and Technology (KNUST), Kumasi, Ghana

Full list of author information is available at the end of the article to the country's Gross Domestic Product (GDP). It also offers job to more than $70 \%$ of the rural households and about $22 \%$ percent of the urban households [1, 2]. Yet, there is widespread poverty among the actors of the sector. The main characteristics of poverty are low levels of income and consumption. Reducing poverty and creating equitable income distribution in rural Ghana have been the central objective of Ghana government. Ministry of Food and Agriculture (MoFA) [3] emphasized original author(s) and the source, provide a link to the Creative Commons licence, and indicate if changes were made. The images or other third party material in this article are included in the article's Creative Commons licence, unless indicated otherwise in a credit line to the material. If material is not included in the article's Creative Commons licence and your intended use is not permitted by statutory regulation or exceeds the permitted use, you will need to obtain permission directly from the copyright holder. To view a copy of this licence, visit http://creativecommons.org/licenses/by/4.0/. The Creative Commons Public Domain Dedication waiver (http://creativeco mmons.org/publicdomain/zero/1.0/) applies to the data made available in this article, unless otherwise stated in a credit line to the data. 
that rural poverty in Ghana is mainly caused by reduced levels of productivity and inefficient functioning of markets for agricultural outputs. Damba et al. [4] reiterated that growth in agricultural productivity is an essential medium that acts as a resolution to poverty and food insecurity issues in developing Africa. However, this medium of improving agricultural productivity is highly dependent on the uptake and utilization of agricultural technology. The application of agricultural technologies is intended to increase local agricultural production through intensification rather than area expansion.

Asante et al. [5] indicated that the agricultural technological innovations have been designed with the objectives of improving food security, increasing incomes and alleviating poverty. The use of agricultural production technologies has an impact on agricultural productivity and growth in the developing world [6]. Similarly, the World Bank [7] was of the opinion that technological innovations in agriculture can trigger a transition from low subsistence agricultural production to a high productivity sector. In Ghana, of all the diverse efforts made by government to improve agricultural productivity, development and dissemination of improved rice technologies appear to attract much attention. Diagne et al. [8] explained that improved rice technologies are farm methods and inputs, tools and machinery, application of knowledge and skills as well as environmental arrangement and procedures that are embraced by the operators to increase local rice production. However, this study places emphasis on farm inputs namely improved rice varieties and chemical fertilizer. The main reasons for the emphasis on the selected improved rice technologies include: (1) rice is gradually becoming a major staple as well as cash crop among cereals; (2) rice is comparable to major food crops such as yam, cassava and plantain in Ghana; (3) rice has the maximum economic potential [9]; (4) Ghana Agricultural Policy documents (Food and Agriculture Sector Development Policy (FASDEP) I \& (FASDEP) II) identify rice as one of the four strategic cereal crops that is capable of ensuring food security [10]; and (5) Ghana spends over 400 million dollars annually in foreign exchange to import rice into the country $[11,12]$. Policy-makers, researchers, marketers and rice producers are all interested in implementing available strategies to increase rice production in Ghana. Therefore, governments' support for farmers over the years to increase rice productivity in order to meet the local demand is commendable.

Evidence exists to suggest a direct relation between uptake of improved agricultural technologies and yield, productivity, income and food security. In Eastern Ethiopia, for instance, Wordofa et al. [13] found that improved agricultural technology adoption resulted in, on average, 23,031.28 Birr (834.42 USD) higher annual farm income per household compared to non-adopters of the technologies. Similarly, Jambo et al. [14] found that participation in small-scale irrigation facility had positive impact on crop production, consumption and revenue generation in Ethiopia. Equally, in Mozambique a study reported that adoption of improved seeds and tractors resulted in an enhanced household income, especially, those households who had better market access [15]. Moreover, a study identified that adoption of improved groundnut varieties in Uganda significantly increased crop income and reduced poverty [16].

Furthermore, in Asia, for example, the widespread acceptance of improved varieties of wheat and rice led to major improvements in farm output and food security [17]. Wiredu et al. [18] observed a positive association between application of improved rice technological innovations and rice productivity and income in Ghana. A study by Awotide et al. [19] reiterated that uptake of improved rice varieties caused an increase in rice yield from $220.93 \mathrm{~kg} / \mathrm{ha}$ to $448.05 \mathrm{~kg} / \mathrm{ha}$ in Nigeria (implying the users had an increase of $267.12 \mathrm{~kg} / \mathrm{ha}$ in rice yield). Minten and Barrett [20] recorded that a percentage increase in rice yields led to a reduction of the number of people experiencing food insecurity by $4.6 \%$ and reduced the average length of the hunger period at the national level by about one-third in Madagascar. In line with this finding, the UK Department for International Development (DFID) predicted that the percentage of poor people living on less than 1 dollar a day is likely to decline between 0.6 and $2 \%$ globally if agricultural productivity falls by $1 \%$ [21].

Despite an ample literature on impact of adoption of agricultural technologies on yield, productivity, income and food security, the association between the uptake of agricultural technology and rural income distribution is scarce. Moreover, the available evidence present mixed results regarding the impact of improved rice seed and income distribution. Kijima et al. [22] found the use of New Rice for Africa (NERICA) caused a decline in poverty levels without influencing rice farmer's income distribution in Uganda. In contrast, Ding et al. [23] observed in Yunnan Province in China that the use of NERICA positively influenced income inequality among the farmers. Such knowledge gap can raise a concern about the role of development assistance in reducing poverty and 
advancing growth in recipient countries [24, 25]. This study, therefore, addresses the question: what is the link between the uptake of improved rice technologies and income distribution in rural Ghana? The objectives of the study are in twofold. First, we assessed the effect of the uptake of improved rice variety and fertilizer on rice farmers' net revenue. Second, we evaluated the impact of the uptake of the technologies on the sample population income distribution.

This study is focused on improved rice varieties and chemical fertilizer whilst both Kijima et al. [22] and Ding et al. [23] studied only NERICA (an improved rice variety). Digne et al. [23] used the counterfactual outcomes framework of modern evaluation theory to estimate the Local Average Treatment Effect (LATE) of NERICA adoption on household expenditure in rural Benin. However, Kijima et al. [22] estimated the plot-level income from NERICA and the alternative crops by Ordinary Least Squares (OLS) and conducted simulation analyses by estimating the household's hypothetical income in the absence of NERICA, under a range of alternative scenarios in rural Uganda. The present study has employed the Bourguignon, Fournier, and Gurgand (BFG), a two-stage model, to check for selectivity bias, and to understand the differential impact of uptake of the selected technology on users and non-users net revenue in rural Ghana. The application of the BFG model has allowed us to study the impact of the uptake decision on farmers' rice net revenue and income distribution. The study will be useful for policy direction to address the problems of poverty and food insecurity in rural Ghana, thereby contributing to the progress toward the achievement of Sustainable Development Goal (SDG) 1 (Eliminate Poverty). The study shall add up to the limited literature on the uptake of agricultural technology and income distribution.

\section{Methods}

\section{Data background}

Rice is an important food crop in Ghana, but the operators are made up of smallholders and over $70 \%$ of them have farm holdings not more than 3 hectares [26]. Rice farming by small-scale farmers is faced with a number of challenges. The vast majority of the farmers continue to invest in low-yielding traditional varieties and farm with subsistent farm equipment. This has pegged the national average yield at 2.4t/ha, even though MoFA has recorded achievable yield of $6 \mathrm{t} / \mathrm{ha}$ [3].

To tackle the low productivity issue, rice scientists/ breeders at The Savanna Agricultural Research Institute (SARI) and Crops Research Institutions (CRI), the two research institutions mandated to address low agricultural productivity, have developed, promoted and disseminated improved rice technologies. The notable among them are improved varieties or seed, organic and chemical fertilizer use, land preparation and management methods and improved post-harvest handling methods [27]. The efficient output of improved rice variety requires, for instance, that farmers also adopt organic or chemical fertilizers and grow the enhanced seed either in upland area or under rain-fed or in muddy environments. In addition, subsidies are provided by the local government to rice farmers to engage in modern rice cultivation. The main reason for government intervention is to improve food security, enhance the operators' income and decrease poverty level at the rural Ghana [5, 7]. According to Schneider et al. [28], when land area is limited, farmers can adapt by using the agricultural technologies to increase productivity. This initiative has been assisted by local extension services to encourage the use of the technologies. This study, therefore, seeks to evaluate the more than three decades of government and development partners efforts to improve rice productivity in Ghana.

\section{Sampling procedure}

The study adopted a multi-stage approach to gather information from a randomly selected 917 rice producers. First, a purposive sampling method was employed to select 26 rice producing communities, comprising 13 communities from Kassena Nanakana and Atwima Nwabiagya Districts in Upper East and Ashanti region, respectively, as shown in Fig. 1.

The main criteria used included: (1) the region should be located at where the two research institutions are located; (2) the districts must have benefited from the promotion and dissemination of the selected technologies for more than a decade; and (3) the number of the rice producers in the selected communities should be at least 100. Based on the set criteria and the use of a proportional sampling technique, the Kassena-Nankana district recorded a sample of 447 respondents and the Atwima Nwabiagya district had 440 respondents.

The study further adopted stratified random sampling to group farmers into users and non-users of the selected technologies at the sampled communities. The stratification led to the selection of a total of 516 users and 401 non-users (to serve as a control group for the study). To ensure that all of the farmers in each stratum have equal chance of being selected, we adopted the randomization function in Microsoft Excel. The users were 


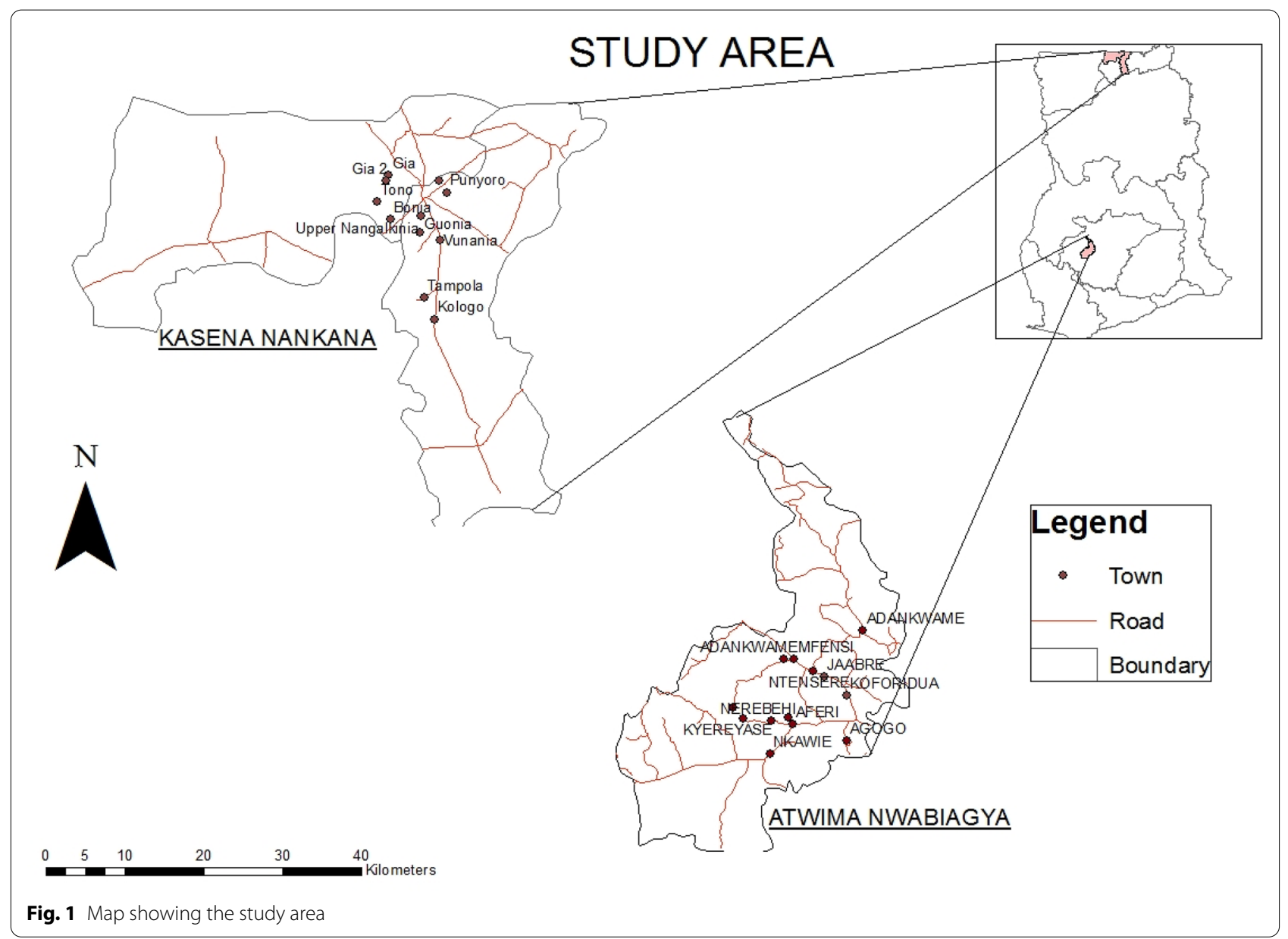

further grouped into the following: users of improved seed only; users of fertilizer only (traditional rice growers who applied only chemical fertilizer); users of fertilizer and enhanced seed combined. Finally, we classified the respondents as follows: $0=$ non-users; $1=$ users of improved seed only; $2=$ users of fertilizer only; and $3=$ users of both fertilizer and improved seed.

\section{Data collection}

Trained local enumerators conducted face-to-face interviews with pre-tested structured questionnaires. Both qualitative and quantitative data were collected. Information elicited included information on socio-economic characteristics of the rice producers, plot-level characteristics, production systems, input use and cost among others. The plot-level characteristics include the size of the plot, the type of rice seed (either traditional seed or improved seed) planted, whether the plot is planted in pure stand or intercropped with other crops and whether chemical fertilizer was applied to the rice seeds or not.
Table 1 presents a summary statistics of the independents variables used for the model estimation. The results indicate that all variables, except total family labour hours variable, are highly significant. This implies that there are variances in the selected variables of users and non-users of the selected technologies. Approximately $81 \%$ of the non-users are women, as compared to men $(22 \%)$ in the same category. The non-users are relatively older ( 51 years), as compare to users ( 44 years). Bekele and Drake [29] reported a negative relationship between age and uptake of improved technology. The labour-demanding nature of improved rice cultivation [30, 31] could explain why relatively younger farmers were users. Both the users' and non-users households record a similar number (8) of adult members. In order to reduce seasonal labour constraints, households having a larger labour endowment are more likely to participate in improved rice cultivation [32]. Monfared [33] found a direct correlation between technology usage and the 
Table 1 Variable name and definition of selected characteristics of farmers using improved and non-improved technologies

\begin{tabular}{|c|c|c|c|c|}
\hline Variable & Description & $\begin{array}{l}\text { Users of improved } \\
\text { technologies }(n=516)\end{array}$ & $\begin{array}{l}\text { Non-improved users } \\
(n=401)\end{array}$ & Mean difference ( $t$-value) \\
\hline Gender & 1 if the farmer is women, 0 otherwise & $0.22(0.41)$ & $0.81(0.39)$ & $-0.59(-22.24)^{* * *}$ \\
\hline Age & Age of respondent (years) & $43.87(12.24)$ & $50.95(13.20)$ & $-7.08(-8.31)^{* * *}$ \\
\hline Adult size & Number of adults in the household & $8.35(2.74)$ & $7.62(2.51)$ & $0.74(4.25)^{* *}$ \\
\hline FSize & Total rice area (acres) & $3.86(2.72)$ & $3.10(3.62)$ & $0.77(3.54)^{* * *}$ \\
\hline Lowner & 1 if farmer own land, 0 otherwise & $0.66(0.47)$ & $0.36(0.48)$ & $0.30(9.65)^{* * *}$ \\
\hline Extension & $\begin{array}{l}1 \text { if a farmer attended relevant extension } \\
\text { training programme, } 0 \text { otherwise }\end{array}$ & $0.39(0.49)$ & $0.18(0.39)$ & $0.21(7.12)^{* * *}$ \\
\hline Seed & Average cost of seed (ghל) & $142.33(192.38)$ & $0.00(0.00)$ & $142.33(16.81)^{* * *}$ \\
\hline $\begin{array}{l}\text { Total Livestock } \\
\text { Unit (TLU) }\end{array}$ & TLU (Total Livestock Unit) & $1.89(4.90)$ & $0.99(3.16)$ & $0.90(3.32)^{* * *}$ \\
\hline Baby & Number of children below 5 years & $2.26(1.49)$ & $3.57(1.52)$ & $-1.31(-13.12)^{* * *}$ \\
\hline Othercrops & Average income from other crops (ghc) & $298.32(572.85)$ & $224.57(478.35)$ & $73.75(2.12)^{* *}$ \\
\hline TFlabour $^{b}$ & $\begin{array}{l}\text { Average total family labour hours employed } \\
\text { by the farmer in the rice production }\end{array}$ & $539.11(194.33)$ & $524.53(169.26)$ & $4.58(1.21)$ \\
\hline
\end{tabular}

Source: Field data, 2016

Estimates in the brackets are standard deviations; ${ }^{* *},{ }^{* * *}$ represent significant differences of $5 \%$ and $1 \%$, respectively

${ }^{a}$ Livestock owned by selected farmers include pig, chicken/guinea fowl, cattle, sheep, goat, donkey, duck. The number of livestock was converted to a single unit known as Tropical Livestock Units (TLU). In line with [57] and [58], approximation of TLU was done by multiplying the mean value of a specific livestock by its respective tropical livestock unit

${ }^{\mathrm{b}}$ Hours are stated on a weekly basis;

Ghana cedis (ghc) and $1 \$=$ gh $\zeta 3.8148$, as at January 2016

amount of family labour available. On average, the users' farm size is larger ( 4 acres), as compared to that of nonusers ( 3 acres). Farm size has been found to influence the use of improved technologies [34, 35]. Majority $(66 \%)$ of users own land in comparison to that of the non-users (36\%). About $39 \%$ of the users claim they participated in relevant extension training, while only $18 \%$ of non-users claim same. The users spend an average of ght 142.33 on improved seeds. Moreover, non-users utilize their own recycled local rice seeds. Overall, a higher TLU (2) is registered by the users as compared to the non-users (1). On average, a smaller number (2) of infants is recorded for the users. In contrast, the non-users registered 4 infants. Child care is likely to limit women participation in enhanced rice cultivation because of its labour intensiveness. Overall, the users obtain higher revenue (ghc 298.32) per hectare from other crops than the non-users (ghष 224.57). Due to the fact that farmers lack access to credit, income from other crops may reduce respondents' liquidity problem.

\section{Empirical strategy to data analysis}

The present study used a more efficient and consistent approach, a two-step Bourguignon, Fournier, and Gurgand (BFG) approach, due to the classification of the respondents into four groups as shown earlier. Ma and Abdulai [36] and Khanal and Mishra [37] adopted this approach due to the classification of their respondents into different categories. This two-stage selectivity correction approach method was put forward by Bourguignon, Fournier, and Gurgand [38] to discover and address selectivity effects created by different choices/classification. Park and others [39] explained that the BFG approach for dealing with selectivity effect has advantages over others because it does not only show the direction of the bias, but also the source of the bias.

\section{Bourguignon, Fournier, and Gurgand (BFG)}

The foremost procedure in our two-step approach consisted of estimating the factors that influence the use of the selected technologies as well as selectivity correction factors to address sample selection bias. We used Multinomial Probit (MNP) model to determine the factors influencing adoption in the first stage of the estimation process. The empirical MNP model to examine the effects of the socio-economic variables on the choices of improved rice technologies $(y)$ is given as follows:

$$
Y_{i}=1 \ldots j=\beta_{0}+\beta_{1} \chi_{1 i}+\beta_{2} \chi_{2 i}+\ldots+\beta_{n} \chi_{n i}+\varepsilon
$$

where $\beta_{0}$ is the intercept, $\beta_{1-n}$ are the coefficients of the various explanatory variables, $\chi_{i-n}$ are the various explanatory variables and $\varepsilon$ is the error term. The 
explanatory variables: age, education, gender, number of infants, number of adults, time allocated to other economic activities, total rice land holding, number of hours of family labour, total livestock unit and hours of communal activities are continuous non-negative variables, while marriage, land ownership, taking part in relevant extension training programmes, perceptions of capital intensive and labour-demanding nature of improved technologies are dummy variables coded with 1 for yes and 0 if otherwise. All these variables were included in the first stage (in the selection equations) of the BFG estimation. However, in the second stage, which is the focus of this study, number of years in schooling, marriage, number of hours of communal activities, hours of engaging in other economic activities, farmers perceptions of capital intensive and labour-demanding nature of the chosen improved rice technologies were excluded since these variables are more associated with the first stage which is the selection equation (Table 1 provides a detailed description of the variables).

The second step to determine the effect of the uptake of the selected technologies on rice farmers' net revenue was the focus of the current study. The net revenue was obtained by subtracting the cost of producing paddy rice per hectare of rice field from gross revenue obtained from the sales of the paddy rice produced from the rice field. At the time of the field work, gh $\$ 3.8148=\$ 1$. If the choice to use a technology is not dependent on the factors that are associated with a farmer's income, then standard OLS regression, devoid of misspecification, would have provided an unbiased estimate of the "average treatment effect" associated with technology usage. Nevertheless, the assumption of independence raises concerns. Therefore, we used the OLS analysis and added the selectivity correction factors produced in stage one of the BFG model estimation. Our OLS regression was specified to determine the factors that impacted on rice farmers' net revenue while other important variables were controlled. As a result, the following specification linking rice farmers' net revenue to farmer and characteristics of household as well as institutional factors was estimated. Thus, we assumed that net revenue of respondents is a linear function of a vector of explanatory variables $\left(X_{i j}\right)$ and user dummy $\left(C_{i j}\right)$ estimated as follows:

$$
Y_{i j}=\beta X_{i j}+\delta C_{i j}+\mu_{i},
$$

where $Y_{i j}$ is the net revenue computed in Ghana Cedis (ghథ), for uptake of improved seed $(j=1)$, fertilizer $(j=2)$ improved seed and fertilizer combined $(j=3)$; $\delta$ and $\beta$ are parameters to be estimated; $\mu_{i}, n_{i}$ denotes residual term in Eqs. (2) and (5) that fulfils $\mu_{i} \sim N(0, \sigma)$.
The main variable of interest is the net revenue of the rice farmers. The subsequent variables, the explanatory variables $\left(X_{i j}\right)$, are introduced as controls. Age is the number of years of the respondent. Adult Size is the number of adult persons in the household; Family Labour hours is the total family members labour participation in terms of hours; Farm size is the total area of the farmer's land holdings; Attend Relevant Extension Training is a dummy variable showing participation in relevant extension training; child refers to number of children below 5 years; and the location dummy variable takes the value of 1 for the Ashanti region.

The choice of the selected technologies is expected to increase rice farmers' net revenue. However, its impact on other crop income is a priori ambiguous. Adult size (holding constant proportion of Labour) is expected to impact positively on farmers' income. Farm size represents inputs into the farm production function, so that its increase is foreseen to result in higher output. The partaking in relevant extension training is believed to increase farmers' incomes (At the time of the field work, $1 \$=$ ght 3.8148). The resources required to raise children and livestock, are expected to decrease rice farmers income (holding all other things constant). The location dummy variable depicts unmeasured characteristics of the agricultural inputs' quality, and its effect is a priori ambiguous.

The problem of selection bias is encountered if unobservable characteristics affect residual term and results in a correlation between the residual terms, i.e. corr $\left(n_{i}, \mu_{i}\right) \neq 0$ if any of the options are chosen $(j=1)$, the outcome equation for net revenue, $\gamma_{1}$ is specified as:

$$
\begin{aligned}
\gamma_{1}= & X \beta_{1}+\delta_{1}\left[\rho_{1}^{*} m\left(P_{1}\right)+\rho_{2}^{*} m\left(P_{2}\right) \frac{P_{2}}{P_{2}-1}\right. \\
& \left.+\rho_{3}^{*} m\left(P_{3}\right) \frac{P_{3}}{P_{3}-1}+\rho_{4}^{*} m\left(P_{4}\right) \frac{P_{4}}{P_{4}-1}\right]+\omega_{1} .
\end{aligned}
$$

In order to obtain an unbiased and consistent estimation, we simultaneously introduced the selectivity correction terms $\left(\eta_{1}^{*}, \eta_{2}^{*}, \eta_{3}^{*}, \eta_{4}^{*}\right)$ estimated in the first-stage in Eq. (4) below:

$$
\begin{aligned}
\gamma_{1}= & X \beta_{1}+\delta_{1}\left[\rho_{1}^{*} m\left(P_{1}\right)+\rho_{2}^{*} m\left(P_{2}\right) \frac{P_{2}}{P_{2}-1}\right. \\
& \left.+\rho_{3}^{*} m\left(P_{3}\right) \frac{P_{3}}{P_{3}-1}+\rho_{4}^{*} m\left(P_{4}\right) \frac{P_{4}}{P_{4}-1}\right] \\
& +\eta_{1}^{*}+\eta_{2}^{*}+\eta_{3}^{*}+\eta_{4}^{*}+\omega_{1},
\end{aligned}
$$

where $m\left(P_{1}\right), m\left(P_{2}\right), m\left(P_{3}\right)$ and $m\left(P_{4}\right)$ are the conditional expectations, $\eta_{1}^{*}, \eta_{2}^{*}, \eta_{3}^{*}$ and $\eta_{4}^{*}$ are termed selectivity 
effects; the standard deviation of the error term from the net revenue equation is denoted as $\sigma ; \omega_{1}$ is the residual term and $\rho$ signifies correlation coefficients between $\eta$ and $\mu$.

The selectivity correction terms in Eq. (4) can be interpreted econometrically as follows: (1) if at least one of the terms is significant, showing the presence of sample selectivity effects as a result of unobservable factors; and (2) when there are insignificant selectivity terms, indicating the absence of selectivity effects. In the first instance, the Endogenous Switching Regression (ESR) model becomes the best choice to determine the causal effect of the given choice of the technology. However, in the second situation, the probit model and the PSM approach becomes the most appropriate method in assessing the related causal effects $[40,41]$.

\section{The ESR model}

From the above outcome and choice equations specified, the respective relationship between the two regimes is represented as:

$$
\begin{aligned}
& C_{1}^{*}=Z \gamma_{1}+\eta_{1}, \\
& Y_{1}=X \beta_{1}+\varphi_{1} \quad \text { if } C_{1}=1, \\
& Y_{0}=X \beta_{0}+\varphi_{0} \quad \text { if } C_{0}=0,
\end{aligned}
$$

where $Y_{1}$ is net revenue given that any of the options are selected $(j=1)$, and $Y_{0}$ is net revenue derived from the non-selection of any of the options $(j \neq 1) ; X$ represents the exogenous variable vector of exogenous variables that affect the net revenue; $\varphi_{1}$ and $\varphi_{0}$ are residual terms, with the mean of zero and is normally distributed.

After the model was estimated in Eq. (5), the inverse Mills ratios $\lambda_{1}$ and $\lambda_{0}$, and the co-variance terms $\sigma_{n 1}=\omega v\left(\eta_{1}, \varphi_{1}\right)$ and $\sigma_{\eta 0}=\omega \nu\left(\eta_{1}, \varphi_{0}\right)$ were calculated and substituted into Eqs. (6) and (7):

$$
\begin{aligned}
& Y_{1}=X \beta_{1}+\sigma_{\eta 1} \lambda_{1}+\zeta_{1} \quad \text { if } C_{1}=1 \\
& Y_{0}=X \beta_{0}+\sigma_{\eta 0} \lambda_{0}+\zeta_{0} \quad \text { if } C_{0}=0
\end{aligned}
$$

where $\lambda_{1}$ and $\lambda_{0}$ are used to control for selection bias as a result of the unobservable factors which includes farmers' inheritability and local institutional environment; the error terms $\xi_{1}$ and $\xi_{0}$ have conditional means of zero.

The effect of uptake of any of the technologies on net revenue was examined by specifying expected values of the outcomes. The variation in the specified outcome equation as a result of a specific choice relative to another choice is specified as the difference between the two options. These outcomes are termed as Average Treatment Effect on Treated (ATT).

The $A T T t_{A T T}^{E S R}$ in this case is:

$$
\begin{aligned}
t_{A T T}^{E S R} & =E\left[Y_{1} \mid C_{1}=1\right]-E\left[Y_{0} \mid C_{1}=1\right] \\
& =X\left(\beta_{1}-\beta_{0}\right)+\left(\sigma_{\eta 1}-\sigma_{\eta 0}\right) .
\end{aligned}
$$

\section{The PSM technique}

PSM could be written as:

$$
\operatorname{Pr}\left(X_{1}\right)=\operatorname{Pr}\left(C_{1}=1 \mid Z_{1}\right)=E\left(C_{1} \mid Z_{1}\right),
$$

where $C_{1}=\{0,1\}$ represents an indicator for selecting the given type of option $(j=1)$ and $Z_{1}$ is the pre-choice characteristic vector. We then estimated the ATT, $t_{A T T}^{P S M}$ as shown below after estimating the propensity scores:

$$
\begin{aligned}
t_{\mathrm{ATT}}^{\mathrm{PSM}}= & E_{p\left(z_{1}\right) D_{1}=1}\left\{E\left[\left(Y_{1} \mid D_{1}=1, P\left(Z_{1}\right)\right)\right]\right. \\
& \left.-E\left[\left(Y_{0} \mid D_{1}=1, P\left(Z_{1}\right)\right)\right]\right\}
\end{aligned}
$$

Various approaches have been adopted to match the selected adopters and non-adopters of the similar propensity score (nearest neighbour matching (NNM), kernel-based matching (KBM) and radius matching methods. For robustness check, a joint consideration of the matching techniques was done (attached as Annex 1 , Table 9). It is worth mentioning that none of the proposed methods in the literature is a priori superior to the others. As a result, we interpreted the results generated from radius matching approach.

\section{Estimation of Gini coefficients}

In order to address the second objective of the study, we simulated what farmers' incomes would be without technology usage (estimated the incomes of non-users), after estimating the income of users of the selected technologies. We then calculate the Gini coefficient for the two scenarios: (i) technology users; and (ii) non-users of the technology. The Gini coefficient was computed using the formula as illustrated below:

$$
G_{c}=\frac{1}{n}\left[n+1-2\left[\frac{\sum_{i=1}^{n}(n+1-i) y_{i}}{\sum_{i=1}^{n} y_{i}}\right]\right] .
$$

This may be simplified to:

$$
G_{c}=\frac{2 \sum_{i=1}^{n} i y_{i}}{n \sum_{i=1}^{n} y i}-\frac{n+1}{n}
$$


where $G_{c}=$ Gini coefficient; $\gamma_{i}=$ number of individuals; $y i=$ income or wealth of individual farmer, for a population uniform on the values $y i$ when $i=1$ to $n$, indexed in an increasing order $\left(y_{i} \leq y_{i}+1\right)$. The value of Gini index ranges from 0 to 1 ranging from complete equity to complete inequity of income distribution. In this study, this equation was used to calculate the Gini coefficient without direct reference to the Lorenz curve.

Farmers' rice income distribution gives a picture of how the net revenue from rice production is shared between users and non-users of the selected agricultural technologies in the study area. According to Buchan [42], the Gini coefficient is a significant indicator for estimating a society's income distribution, a significant attribute that reflects economic sustainability of that society.

\section{Results and discussion}

Determining the factors that influence the uptake of the selected technologies in the study area: first-stage BFG estimation

The determinants of uptake of improved rice varieties and chemical fertilizer are determined from BFG first stage, using Multinomial Probit (MNP) regression estimates of rice producers' alternative choices. The MNP was employed because in the dissemination of bundle of technologies, farmers' adoption decision is a dependent

Table 2 Determinants of uptake of improved rice varieties and fertilizer: BFG first stage

\begin{tabular}{|c|c|c|c|c|c|c|}
\hline \multirow{2}{*}{$\begin{array}{l}\text { Independent } \\
\text { variable }\end{array}$} & \multicolumn{2}{|c|}{ Improved rice variety } & \multicolumn{2}{|l|}{ Fertilizer application } & \multicolumn{2}{|c|}{ Both rice variety and fertilizer } \\
\hline & Coeff (std. err) & $\begin{array}{l}\text { Marginal effect } \\
\text { (std. err) }\end{array}$ & Coeff (std. err) & $\begin{array}{l}\text { Marginal effect } \\
\text { (std. err) }\end{array}$ & Coeff (std. err) & $\begin{array}{l}\text { Marginal effect } \\
\text { (std. err) }\end{array}$ \\
\hline Gender & $-1.2828(0.4170)^{* * *}$ & $-0.0499(0.0591)$ & $-0.1453(0.4745)$ & $-0.1574(0.0434)^{* * *}$ & $-3.7187(0.7577)^{* * *}$ & $-0.3638(0.0813)^{* * *}$ \\
\hline Ln_Age & $-0.5576(0.2249)^{* *}$ & $-0.0407(0.0251)$ & $-1.6143(0.3065)^{* * *}$ & $-0.0830(0.0222)^{* * *}$ & $-1.2932(0.2797)^{* * *}$ & $-0.0615(0.0252)^{* *}$ \\
\hline Ln_Years_Sch & $0.1455(0.0950)$ & $0.0126(0.0104)^{*}$ & $0.1737(0.1125)$ & $0.0096(0.0082)$ & $0.0628(0.1066)$ & $0.0079(0.0095)$ \\
\hline Marriage & $-1.3020(0.2741)^{* * *}$ & $-0.0468(0.0249)^{*}$ & $-1.6572(0.3033)^{* * *}$ & $-0.0573(0.0186)^{* * *}$ & $-1.5837(0.2943)^{* * *}$ & $-0.0489(0.0212)^{* *}$ \\
\hline Ln_Adults_size & $0.1207(0.3159)$ & $-0.0079(0.0208)$ & $0.1215(0.3190)$ & $0.0041(0.0113)$ & $0.1024(0.3172)$ & $0.0004(0.0116)$ \\
\hline Ln_Farm_Size & $0.4629(0.1561)^{* * *}$ & $0.0061(0.0187)$ & $0.5292(0.1850)^{* * *}$ & $0.0078(0.0143)$ & $0.7575(0.1951)^{* * *}$ & $0.0431(0.0194)^{* *}$ \\
\hline Land_Ownership & $0.6389(0.2592)^{* *}$ & $0.0290(0.0272)$ & $1.4902(0.3225)^{* * *}$ & $0.1028(0.0234)^{* * *}$ & $0.4048(0.2770)$ & $0.0461(0.0238)^{*}$ \\
\hline $\begin{array}{l}\text { Attend_Train- } \\
\text { ing_Prog }\end{array}$ & $0.3483(0.2232)$ & $-0.000(0.0237)$ & $0.4982(0.2571)$ & $0.0131(0.0180)^{*}$ & $0.6162(0.2480)$ & $0.0343(0.0213)^{* *}$ \\
\hline $\begin{array}{l}\text { Percieved_Lab_ } \\
\text { Inten_Imp_seed }\end{array}$ & $-0.4515(0.2252)^{* *}$ & $-0.0814(0.0239)^{* * *}$ & $0.2309(0.2619)$ & $-0.0255(0.0183)$ & $-0.1774(0.2496)$ & $-0.0407(0.0214)^{*}$ \\
\hline $\begin{array}{l}\text { Percieved_Lab_ } \\
\text { Inten_Fert_Use }\end{array}$ & $-0.0677(0.2409)$ & $-0.0768(0.0241)^{* * *}$ & $-1.3620(0.2716)^{* * *}$ & $-0.0893(0.0190)^{* * *}$ & $-0.8445(0.2554)^{* * *}$ & $-0.0471(0.0210)^{* *}$ \\
\hline $\begin{array}{l}\text { Percieved_Cap_ } \\
\text { Inten_Fert_Use }\end{array}$ & $-0.0040(0.2455)$ & $-0.0588(0.0243)^{* *}$ & $-0.7861(0.2762)^{* * *}$ & $-0.0468(0.0185)^{* *}$ & $-0.6405(0.2654)^{* *}$ & $-0.0478(0.0211)^{* *}$ \\
\hline Ln_seed_cost & $-0.1817(0.0515)^{* * *}$ & $-0.0199(0.0049)^{* * *}$ & $-0.2448(0.0637)^{* * *}$ & $-0.0339(0.0038)^{* * *}$ & $-0.1982(0.0553)^{* * *}$ & $-0.0218(0.0039)^{* * *}$ \\
\hline In_TLU & $-0.2270(0.1114)^{* *}$ & $-0.0342(0.0113)^{* * *}$ & $-0.1349(0.1250)$ & $-0.0095(0.0086)$ & $0.0819(0.1204)$ & $0.0289(0.0098)^{* * *}$ \\
\hline $\begin{array}{l}\text { Ln_Hours_Other_ } \\
\text { Eco_Act }\end{array}$ & $-0.2458(0.3471)$ & $-0.1719(0.0376)^{* * *}$ & $-1.6489(0.4076)^{* * *}$ & $-0.0424(0.0285)$ & $-2.6795(0.3962)^{* * *}$ & $-0.2467(0.0343)^{* * *}$ \\
\hline Ln_Infants_cent & $-1.1285(0.5919)^{*}$ & $-0.0275(0.0408)$ & $-1.7505(0.6059)^{* * *}$ & $-0.0748(0.0244)^{* * *}$ & $-1.4560(0.5940)^{* *}$ & $-0.0408(0.0247)^{*}$ \\
\hline $\begin{array}{l}\text { Ln_Hours_Com_ } \\
\text { activities }\end{array}$ & $-4.6982(0.7081)^{* * *}$ & $-0.4163(0.0736)^{* * *}$ & $-3.7439(0.8125)^{* * *}$ & $-0.1209(0.0562)^{* *}$ & $-2.6220(0.8041)^{* *}$ & $-0.1133(0.0691)$ \\
\hline Location & $0.6711(0.2966)^{* *}$ & $0.0768(0.0302)^{* *}$ & $0.7448(0.3327)^{* *}$ & $0.0497(0.0222)^{* *}$ & $0.0091(0.3073)$ & $0.0681(0.0250)^{* * *}$ \\
\hline $\begin{array}{l}\text { Ln_Income_Other_ } \\
\text { Crop }\end{array}$ & $0.0002(0.0002)$ & $-0.0000(0.0000)$ & $0.0002(0.0002)$ & $-0.0000(0.0000)$ & $0.0007(0.0002)^{* * *}$ & $0.0001(0.0000)^{* * *}$ \\
\hline Constant & $13.0434(2.0447)^{* * *}$ & & $16.0160(2.4475)^{* * *}$ & & $13.8671(2.3192)^{* * *}$ & \\
\hline
\end{tabular}

Source: authors own computation, 2016

No. Obs $=917$

LR for all coefficient $\mathrm{Chi}^{2}(66)=436.63^{* * *}$

LR for non-interacted terms $\mathrm{Chi}^{2}(57)=422.90^{* * *}$

LR for interacted terms $\mathrm{Chi}^{2}(9)=59.93 * * *$

Log likelihood $=-551.9129$

$\mathrm{VIF}=1.31$ 
variable. MNP has errors which are not independent, and are distributed by a multivariate normal distribution [43]. There are limitations associated with the interpretation of the coefficient, therefore, the marginal effect values are used to interpret the magnitudes of the determinants of rice producers' alternative choices. However, the signs of the coefficients show the direction of the marginal effects. The results are presented in Table 2 below. According to Table 2, the log-likelihood ratio (LR) for all coefficients, non-interacted terms and interacted terms are all found to be highly significant at the $1 \%$ level. This means that all the explanatory variables that are included in the model jointly influenced farmers' probability of uptake of improved rice varieties and fertilizer. The average variance inflation factors (VIF) computed is 1.31 . This value falls below the minimum value of 5 (used as the rule of thumb) to indicate the presence of multicollinearity [44]. This indicates that multicollinearity has been taken care of in the models estimation.

Due to the fact that the main focus of the study is to evaluate the impact of adoption on income distribution, we shall briefly present the results of Table 2 . According to Table 2, the Multinomial Probit estimates show that education, farm size, land ownership, participation in extension training programme, location, and income from other crops enhance adoption. In contrast to this, gender (female), participation in domestic work, age, marriage, perceived labour-demanding and capital intensive, seed cost, total livestock unit, hours spent to engage in other economic activities, child care and hours of communal activities inhibit adoption of improved rice technologies. Our finding relating to the influence of gender and farm size on the selected agricultural technologies adoption is consistent with that of Santeramo et al. [45] in Italy and [46] in Ghana. However, with regard to education, our finding lends support to Leake and Adam [47] in Northern Ethiopia, but is inconsistent with that of Santeramo et al. [45] in Italy. Similarly, the finding pertaining to a positive relationship between land ownership and adoption is found to be in line with that of Teklewold et al. [48] in Uganda. Furthermore, our finding with regard to a positive correlation between extension training and adoption supports that of Cerdan-Infantes et al. [49] in Uruguay.

Table 3 The factors that affect farmers' net revenue per acre in the study area

\begin{tabular}{lllll}
\hline Independent variable & Non-users $(\boldsymbol{n}=\mathbf{4 0 1})$ & Improved rice variety only & Fert Fertilizer only & $\begin{array}{l}\text { Improved variety plus } \\
\text { fertilizer combination } \\
\text { Coeff (std err) }\end{array}$ \\
\hline Gender & Coeff (std err) & Coeff (std err) & Coeff (std err) & $-0.4512^{*}(0.2498)$ \\
Ln_Age & $-0.4594(0.2952)$ & $-0.3326(0.3811)$ & $-0.5861^{*}(0.3330)$ & $-0.0592^{*}(0.0397)$ \\
Ln_Adult_size & $0.0679(0.0892)$ & $-0.1938^{* * *}(0.0565)$ & $-0.1717^{*}(0.0878)$ & $1.0201^{* * *}(0.0955)$ \\
Ln_Farm_Size & $0.6624^{* * *}(0.1894)$ & $0.7917^{* * *}(0.2026)$ & $0.8466^{* * *}(0.2321)$ & $0.0747^{* *}(0.0338)$ \\
Land_Ownership & $0.0984^{* *}(0.0420)$ & $0.1863^{* * *}(0.0561)$ & $0.1146^{*}(0.0671)$ & $-0.0234(0.0921)$ \\
Attend_Training_Prog & $0.7675^{* * *}(0.2180)$ & $-0.1535(0.1831)$ & $-0.0968(0.2577)$ & $0.0006(0.0783)$ \\
Ln_seed_cost & $-0.0457(0.1611)$ & $0.2033^{*}(0.1491)$ & $0.0877(0.1607)$ & $-0.0237^{* *}(0.0096)$ \\
Ln_TLU & $-0.0068(0.0214)$ & $-0.0235(0.0110)$ & $-0.0250(0.0238)$ & $0.0099(0.0144)$ \\
Ln_Other_crop_income & $0.0016(0.0372)$ & $-0.0171(0.0210)$ & $0.1358^{* * *}(0.0476)$ & $0.0573^{*}(0.0347)$ \\
Ln_Infants_cent & $-0.0056(0.0223)$ & $0.0085(0.0363)$ & $-0.1245^{*}(0.0859)$ & $-0.0887^{* * *}(0.0333)$ \\
Location & $-0.0778(0.1332)$ & $-0.1634^{* *}(0.0782)$ & $0.0710(0.2040)$ & $0.2615^{* *}(0.1117)$ \\
Mills0 & $0.2824(0.2456)$ & $0.2795(0.2222)$ & $-0.0001(0.0066)$ & $0.0005(0.0028)$ \\
Mills1 & $0.1798^{* *}(0.0758)$ & $0.0007(0.0073)$ & $0.0015(0.0151)$ & $-0.0048(0.0051)$ \\
Mills2 & $-0.0096(0.0131)$ & $0.0020(0.0101)$ & $-0.0030(0.0120)$ & $0.0103(0.0054)$ \\
Mills3 & $0.0072(0.0134)$ & $-0.0073(0.0114)$ & $-0.0006(0.0076)$ & $0.0064(0.0075)$ \\
Constant & $0.0077(0.0099)$ & $0.0150(0.0119)$ & $7.2933^{*}(3.7873)$ & $7.9742^{* * *}(1.5134)$ \\
Adj. R-squared & $12.9685^{*}(7.8474)$ & $15.2192^{* *}(6.2244)$ & 0.6081 & 0.0 .6861 \\
Wald test for all coefficient & 0.4823 & 0.5867 & $F(20,81)=2.78^{* * *}$ & $F(20,229)=2.30^{* * *}$ \\
Observation & $F(20,381)=2.22^{* * *}$ & $F(20,144)=4.12^{* * *}$ & 103 & 249 \\
\hline Source:Sury & 401 & 164 & &
\end{tabular}

Source: Survey data, 2016

Values in the parentheses are standard errors; In is natural log; cent is centred; the dependent variable is the log of net revenue of rice production; and reference location is the Kassena Nankana District in the Upper East Region of Ghana 
Assessing the factors that affect rice farmers' net revenue per acre in the study area: second-stage BFG estimation

From Table 3, to test whether there is an association between the value of the parameter and the outcome equation, the study adopts the Wald test. The test suggests that the parameter is associated with the outcome since the p-values of all the coefficients are significant at $1 \%$. The result shows no significant selectivity correction in terms of the farmers' alternatives. Hence, PSM is utilized to approximate the ATT after estimating propensity scores using Probit model (Annex 1: Tables 6, 7, 8).

From Table 3, the result indicates that gender has an inverse but significant effect on net revenue. In Ghana, society assigns domestic work to women and assigns productive/farm work to men. This attribution prevents women from devoting full time to rice productive activities which could impact negatively on net revenue. Similarly, age has a negative and significant effect on net revenue. In contrast, Abdulai and Huffman [50] recorded no significant impact of age on net revenue for both adopters and non-adopters in Ghana. This could be explained by the fact that field ridging technology is less labour intensive than improved rice cultivation. However, there is a positive and significant relationship between net revenue of the farmer and the number of adult household members. There is a relationship between the number of adults in farm household and labour availability for productive activities. At a typical farm household, most of the adult members are either directly or indirectly involved in farming. Therefore, the presence of adult household members in a farm household could decreases the risk of not having enough labour and encourages farmers to take risks to invest in improved rice cultivation.
Farm size significantly relates to both the users and non-users net revenue positively. Notably, the impact of farm size on net revenue is greater among users than non-users. This could be explained by the fact that the users of the technologies increase net revenues through expansion in the land area of cultivation and intensification. This is inconsistent with the indirect relationship between farm size and productivity which implies smaller farms are highly productive than larger farms $[51,52]$. This inverse situation should be possible under a system of rice intensification. Zhuo and others observed that the empirical inverse relationship recorded in China could be explained by the failure to account for the unobserved land quality that was unevenly distributed across the farm size continuum, rather than taking it as the case for China's agriculture [53].

There is a positive and significant relationship between land ownership and non-adopters' net revenue. This is understandable because farmers seldom consider farming as business, thus, land owners do not factor land price into cost of production. Farmers who attend extension training programmes are able to increase net revenue, showing participation in relevant training programme enhances efficiency of production. Access to extension services has been found to be positively and significantly associated with the use of improved technologies [53, 54 ]. Seed cost has a negative impact on users of improved rice variety plus fertilizer's net revenue, indicating that cost of farm inputs reduces the net benefits. A farmer who engages in other economic activities obtains higher net revenue from improved rice cultivation. Abdulai and Huffman [37] have indicated that income earn from other income generating activities could be used to acquire resources like labour and fertilizer to increase productivity and net revenues. This could also suggest

Table 4 Average treatment effect of improved rice technologies adoption on net revenue per acre: PSM estimation

\begin{tabular}{|c|c|c|c|c|c|}
\hline \multirow[t]{2}{*}{ Matching Algorithm } & \multicolumn{5}{|l|}{ Mean outcomes } \\
\hline & $\begin{array}{l}\text { Improved seed users } \\
(n=164)\end{array}$ & Non- Users $(n=401)$ & ATT & $t$-value & Change (\%) \\
\hline Radius & 1017.80 & 630.95 & 386.85 & $8.11^{* * *}$ & 61.31 \\
\hline Matching Algorithm & $\begin{array}{l}\text { Fertilizers users ( } n \\
=103 \text { ) }\end{array}$ & Non-users $(n=401)$ & ATT & $t$-value & Change (\%) \\
\hline Radius & 1175.61 & 630.95 & 544.66 & $7.31^{* * *}$ & 86.32 \\
\hline Matching Algorithm & $\begin{array}{l}\text { Users of the two } \\
\text { technologie ( } n= \\
249)\end{array}$ & Non-users $(n=401)$ & ATT & $t$-value & Change (\%) \\
\hline Radius & 1599.74 & 630.95 & 968.79 & $23.67^{* * *}$ & 153.54 \\
\hline
\end{tabular}

Source: Survey data, 2016

ATT, average treatment effect on the treated 
specialisation within the household. Households with larger labour (large adult size) may assign other members to other activities without any adverse consequences on farm activity.

Child care variable reduces users' net revenue significantly. This indicates that the greater the number of children the less the time to invest in rice cultivation. This situation is likely to affect women more than men because it is a woman responsibility to take care of children in Ghana. Location significantly increases net revenue, suggesting users of the technologies who reside in the south obtain higher net revenue than those in the north. The high incidence of poverty in the north is likely to prevent the users to apply the right quantities of the selected technologies to fully benefit from their usage.

\section{Evaluating the impact of the selected technologies uptake on rice producers' net revenue per an acre of rice field: PSM estimation}

This section examines the impact of selected improved technologies uptake on farmers' rice income, by comparing income of farmers who used the enhanced technologies and those who did not. Table 4 shows the results of the ATT, thus, the causal effect of users' choices on net revenue.

The result shows that the choice of improved rice varieties only tends to significantly increase net revenue per acre by $61.31 \%$ when non-users are treated as the control group. Similarly, the choice of fertilizer only tends to significantly increase net revenue by $86.32 \%$, while that of the users of improved rice variety and fertilizer combination increases by $153.54 \%$. The findings suggest that the causal effect of improved rice variety plus fertilizer on net revenue is highest (gh\$ 1,339.28), followed by fertilizer application (gh\$ 544.66) and finally by improved rice varieties cultivation (ghథ 386.95 ) (Table 4 , and details in Annex 1: Table 9). This agrees with similar findings in Ghana, Nigeria, Madagascar and Ethiopia, respectively $[18-20,55]$. As farmers' rice incomes increase, the households are more likely to have more funds to purchase food. According to Nata et al., [56], increasing farm income decreases the probability of households being food insecure and increases the probability of the households falling outside the category of the vulnerable group. Similarly, Babatunde and Qaim [55] showed a positive relationship between income and food security.

\section{Gini decomposition of rice income by sources}

Table 5 presents Gini decomposition by sources and by the population sub-groups. Generally, there is a fair distribution of rice income among respondents in the study area since the highest Gini coefficient among women non-user is 0.582 . In addition, analysis of Gini coefficient reveals that the degree of income inequality is lowest (0.325) in men users. The source elasticity of total inequality suggests that, for instance, a $100 \%$ increase in men uptake of improved rice variety plus fertilizer combination, men uptake of improved rice seed only and women uptake of fertilizer only reduce the overall income inequality by $9 \%, 5 \%$ and $1.7 \%$, respectively (Table 5 ). The result implies that the aforementioned income sources have an equalizing effect on overall income inequality. Strikingly, women users of improved rice variety plus fertilizer combination record the greatest percentage

Table 5 Gini decomposition of rice income by income source and the population sub-groups

\begin{tabular}{|c|c|c|c|c|c|c|}
\hline Source & $\begin{array}{l}\text { Net } \\
\text { revenue } \\
\text { per acre }\end{array}$ & $\begin{array}{l}\text { Income } \\
\text { share } \\
\left(S_{k}\right)\end{array}$ & $\begin{array}{l}\text { Gini } \\
\text { coefficient } \\
\left(G_{k}\right)\end{array}$ & $\begin{array}{l}\text { Correlation with total } \\
\text { income distribution } \\
\left(R_{\mathrm{k}}\right)\end{array}$ & $\begin{array}{l}\text { Percentage contribution } \\
\text { to total income Inequality } \\
\left(S_{k} G_{k} R_{k} / G\right)\end{array}$ & $\begin{array}{l}\text { Source elasticity of total } \\
\text { inequality }\left(S_{k} G_{k} R_{k} / G\right)-S_{k}\end{array}$ \\
\hline $\begin{array}{l}\text { Men improved rice variety } \\
\text { users income }\end{array}$ & 1213.60 & 0.127 & 0.325 & 0.596 & 7.8 & -0.050 \\
\hline $\begin{array}{l}\text { Women improved rice } \\
\text { variety users income }\end{array}$ & 1140.20 & 0.119 & 0.401 & 0.852 & 12.8 & 0.009 \\
\hline Men fertilizer users income & 1424.33 & 0.149 & 0.544 & 0.679 & 17.4 & 0.025 \\
\hline $\begin{array}{l}\text { Women fertilizer users } \\
\text { income }\end{array}$ & 1200.50 & 0.125 & 0.329 & 0.832 & 10.8 & -0.017 \\
\hline $\begin{array}{l}\text { Men rice variety plus ferti- } \\
\text { lizer users income }\end{array}$ & 1682.08 & 0.187 & 0.395 & 0.403 & 9.4 & -0.090 \\
\hline $\begin{array}{l}\text { Women rice variety plus } \\
\text { fertilizer users income }\end{array}$ & 1469.78 & 0.153 & 0.515 & 0.859 & 21.4 & 0.061 \\
\hline Men non-users & 773.00 & 0.081 & 0.582 & 0.865 & 12.9 & 0.047 \\
\hline Women non-users & 561.30 & 0.059 & 0.466 & 0.859 & 7.5 & 0.016 \\
\hline Total & 9591.05 & 1 & 0.317 & & 100 & \\
\hline
\end{tabular}

Source: Survey data, 2016 
contribution (21.4\%) to total inequality, suggesting that the inequality is greatest among them.

Finally, the result suggests that the use of the selected improved rice technologies relatively reduces the income inequality of women rice producers from 0.466 to 0.317 ( 0.149 points lower than the total income inequality), and also relatively reduces that of their men counterparts from 0.582 to 0.317 ( 0.265 points lower than the total income inequality). Thus, on average, uptake reduces the respondents' rice income inequality by 0.207 points, suggesting uptake has equalizing effect. This outcome of the study supports that of Ding et al. [23] who observed a positive outcome among Yunnan Province farmers in China. However, the result is inconsistent with that of Kijima et al. [22] who reported that NERICA adoption has a neutral impact on income distribution of men and women rice farmers in Uganda.

\section{Conclusions and recommendation}

The present study evaluates the role of agricultural technologies in rural income distribution in Ghana. The study uses primary dataset from rice producers and employs a two-step BFG model to identify causal effects of the selected technologies usage on net revenue. The result of the descriptive statistics implies significant differences in some key socio-economic and demographic characteristics between users and non-users of the selected technologies. To control for such differences and allow a causal interpretation of the impact of the use of the selected technologies, the study has estimated the dataset using the two-step BFG model. The empirical results show that education, farm size, land ownership, participation in relevant extension training programmes enhance adoption, while gender (female) inhibits uptake of the selected technologies. The empirical result has further found factors such as gender, age, seed cost and number of children negatively impact on the net revenue per acre while economically active household members, farm size, participation in relevant extension training, income from other income generating activities, hours of family labour used to support farm activities and location impact positively on the net revenue. Our finding also shows that uptake of only improved rice varieties, fertilizer and the combination of the two selected technologies tends to significantly increase net revenue by $61.31 \%$ (ghథ 386.85 ), 86.32\% (ghc 544.66) and 153.54\% (ghc 968.79), respectively. This suggests that, on average, the uptake of the selected technologies significantly increases rice farmers' net revenue by 100.39 percentage points. The study has also shown that the uptake of the selected technologies, on average, decreases the income inequality of the rice farmers in the study area by 0.207 points, suggesting uptake has an equalizing effect. The study concludes that the use of the selected technologies can play an important role in fighting against poverty in rural Ghana.

This study supports broader investment in improved rice technologies to address low productivity of local rice. Reaching the farm operators with improved rice technologies however necessitates policy support for improving extension services and access to resources, especially land to simulate adoption. Finally, due to the fact that the uptake increases income and decreases income inequality in the study area, the study recommends that the National Development Planning Commission (NDPC) strategies for redistribution of wealth in Ghana should incorporate promotion and dissemination of improved rice technologies.

\section{Annex 1}

See Tables 6, 7, 8, 9.

Table 6 Probit estimates of propensity score for adoption of improved rice variety only

\begin{tabular}{llll}
\hline Variable & Coefficient & Std. err & z-value \\
\hline Gender & -2.0152 & 0.6626 & $-3.04^{* * *}$ \\
Log_Age & -1.5472 & 0.6962 & $-2.22^{* *}$ \\
log_Years_Sch & 0.0108 & 0.1420 & 0.08 \\
Marital_Status & -0.7921 & 0.3606 & $-2.20^{* *}$ \\
Eco_Active_HH & 0.2902 & 0.0732 & $3.96^{* * *}$ \\
log_Farm_Size & 0.2624 & 0.2462 & 1.07 \\
Land_Ownership & 0.4401 & 0.4089 & 1.08 \\
Attend_Training_Prog & 0.6010 & 0.3081 & $1.95^{*}$ \\
Lab_Inten_Imp_Rice_Var & -0.1709 & 0.2970 & -0.58 \\
Log_seed_cost & -0.3422 & 0.0675 & $-5.07^{* * *}$ \\
log_TLU & -0.0205 & 0.1709 & -0.12 \\
Log_Hours_Other_Eco_Act & -1.4255 & 0.6976 & $-2.04^{* *}$ \\
Log_Infants_cent & -1.5656 & 0.4682 & $-3.34^{* * *}$ \\
Log_Hours_Com_activities & -8.8679 & 1.4914 & $-5.95^{* * *}$ \\
Main_Act_Most_Time_Spent & -0.3688 & 0.3248 & -1.14 \\
Location & 1.1381 & 0.3026 & $3.76^{* * *}$ \\
Income_Other_Crop & 0.0003 & 0.0003 & 1.16 \\
Gen_Land_Own & 1.5005 & 0.6478 & $2.32^{* *}$ \\
Gen_Infants_cent & -1.8804 & 0.4958 & $-3.79^{* * *}$ \\
Constant & 23.5505 & 4.1772 & $5.64^{* * *}$ \\
Pseudo-R ${ }^{2}$ & 0.8369 & & \\
Loglikelihood & -48.2737 & & \\
Observations & 606 & & \\
\hline & & & \\
\hline & & & \\
\hline
\end{tabular}


Table 7 Probit estimates of propensity score for adoption of Fertilizer application only

\begin{tabular}{llll}
\hline Variable & Coefficient & Std. err & z-value \\
\hline Gender & -6.5913 & 2.7276 & $-2.42^{* *}$ \\
Log_Age & -2.1854 & 1.4886 & -1.47 \\
log_Years_Sch & 0.0407 & 0.3960 & 0.10 \\
Marital_Status & -4.5316 & 1.8571 & $-2.44^{* *}$ \\
Eco_Active_HH & 0.7234 & 0.2616 & $2.77^{* * *}$ \\
log_Farm_Size & 0.0270 & 0.6343 & 0.04 \\
Land_Ownership & 5.6595 & 2.1655 & $2.61^{* * *}$ \\
Attend_Training_Prog & 1.7667 & 0.8360 & $2.11^{* *}$ \\
Lab_Inten_Fert_Use & -4.2580 & 1.5498 & $-2.75^{* * *}$ \\
Cap_Inten_Fert_Use & -4.1990 & 1.8155 & $-2.31^{* *}$ \\
log_TLU & -0.5215 & 0.3355 & -1.55 \\
Log_Hours_Other_Eco_Act & -9.4689 & 3.6830 & $-2.57^{* * *}$ \\
Log_Infants_cent & -5.6025 & 1.9226 & $-2.91^{* * *}$ \\
Log_Hours_Com_activities & -12.0589 & 5.4591 & $-2.21^{* *}$ \\
Main_Act_Most_Time_Spent & -2.8784 & 1.6205 & $-1.78^{*}$ \\
Location & 4.4825 & 1.7729 & $2.53^{* *}$ \\
Income_Other_Crop & 0.0016 & 0.0009 & $1.87^{*}$ \\
Gen_Land_Own & 2.4199 & 1.9123 & 1.27 \\
Gen_Infants_cent & -0.5488 & 0.3318 & $-1.65^{*}$ \\
Constant & 36.4770 & 16.8289 & $2.17^{* *}$ \\
Pseudo-R & 0.9322 & & \\
Log likelihood & -15.4036 & & \\
Observations & 568 & & \\
\hline & & & \\
\hline & & & \\
\hline
\end{tabular}

Table 8 Probit estimates of propensity score for adoption of improved rice seed and fertilizer combination application

\begin{tabular}{llll}
\hline Variable & Coefficient & Std. err & z-value \\
\hline Gender & -2.6656 & 0.9370 & $-2.84^{* * *}$ \\
Log_Age & -0.3925 & 0.4107 & -0.96 \\
log_Years_Sch & 0.2049 & 0.0960 & $2.13^{* *}$ \\
Marital_Status & -0.2338 & 0.2009 & -1.16 \\
Eco_Active_HH & 0.0395 & 0.0337 & 1.17 \\
log_Farm_Size & 0.1381 & 0.2276 & 0.61 \\
Land_Ownership & 0.3784 & 0.2326 & 1.63 \\
Attend_Training_Prog & 0.4365 & 0.2029 & $2.15^{* *}$ \\
Lab_Inten_Imp_Rice_Var & -0.3629 & 0.2052 & $-1.77^{*}$ \\
Lab_Inten_Fert_Use & -0.3071 & 0.2316 & -1.33 \\
Cap_Inten_Fert_Use & -1.3206 & 0.2130 & $-6.20^{* * *}$ \\
Log_seed_cost & -0.0779 & 0.0464 & $-1.68^{*}$ \\
log_TLU & 0.2830 & 0.0949 & $2.98^{* * *}$ \\
Log_Hours_Other_Eco_Act & -2.3951 & 0.3974 & $-6.03^{* * *}$ \\
Log_Infants_cent & -0.2484 & 0.1879 & -1.32 \\
Log_Hours_Com_activities & -0.8428 & 0.7330 & -1.15 \\
Main_Act_Most_Time_Spent & -0.2673 & 0.2528 & -1.06 \\
Location & 0.6989 & 0.2552 & $2.74^{* * *}$ \\
Income_Other_Crop & 0.0006 & 0.0002 & $3.18^{* * *}$ \\
Gen_Land_Own & 0.0987 & 0.6431 & 0.15 \\
Gen_Infants_cent & -1.6011 & 0.5485 & $-2.92^{* * *}$ \\
Constant & 0.9554 & 2.2036 & 0.43 \\
Pseudo-R ${ }^{*}$ & 0.5020 & & \\
Loglikelihood & -110.5123 & & \\
Observations & 723 & & \\
\hline & & & \\
\hline & & & \\
\hline
\end{tabular}


Table 9 Average treatment effect of improved rice technologies adoption net income per acre: PSM estimation

\begin{tabular}{|c|c|c|c|c|c|}
\hline \multirow[t]{2}{*}{ Matching Algorithm } & \multicolumn{5}{|l|}{ Mean Outcomes } \\
\hline & $\begin{array}{l}\text { Rice variety } \\
\text { users }(n=164)\end{array}$ & Non-users $(n=401)$ & ATT & $t$-value & Change (\%) \\
\hline NNM & 1017.80 & 261.24 & 756.57 & $2.13^{* *}$ & 289.61 \\
\hline KBM & 906.99 & 524.39 & 382.60 & $2.14^{* *}$ & 72.96 \\
\hline Radius & 1017.80 & 630.95 & 386.85 & $8.11^{* * *}$ & 61.31 \\
\hline Matching algorithm & $\begin{array}{l}\text { Rice variety } \\
\text { users }(n=164)\end{array}$ & Fertilizer users $(n=103)$ & ATT & $t$-value & Change (\%) \\
\hline NNM & 1017.80 & 1224.15 & -206.35 & -0.95 & -16.86 \\
\hline KBM & 1017.80 & 1288.51 & -270.71 & -1.50 & -21.01 \\
\hline Radius & 1017.80 & 1175.61 & -157.81 & $-3.40^{* * *}$ & -13.42 \\
\hline Matching algorithm & $\begin{array}{l}\text { Rice variety } \\
\text { users }(n=164)\end{array}$ & $\begin{array}{l}\text { Both rice variety and fertilizers } \\
\text { users }(n=249)\end{array}$ & ATT & $t$-value & Change (\%) \\
\hline NNM & 1017.80 & 1578.31 & -560.50 & $-4.01^{* * *}$ & -35.51 \\
\hline KBM & 1020.80 & 1552.71 & -531.91 & $-4.81^{* * *}$ & -34.26 \\
\hline Radius & 1017.80 & 1599.74 & -581.94 & $-12.44^{* * *}$ & -36.38 \\
\hline Matching algorithm & Fertilizers users $(n=103)$ & Non-users $(n=401)$ & ATT & $t$-value & Change (\%) \\
\hline NNM & 1175.61 & 149.86 & 1025.75 & $2.73^{* * *}$ & 684.47 \\
\hline KBM & 886.40 & 636.73 & 249.67 & 1.29 & 39.21 \\
\hline Radius & 1175.61 & 630.95 & 544.66 & $7.31^{* * *}$ & 86.32 \\
\hline Matching algorithm & Fertilizers users $(n=103)$ & Rice variety users $(n=164)$ & ATT & $t$-value & Change (\%) \\
\hline NNM & 1175.61 & 1037.97 & 137.65 & 0.91 & 13.26 \\
\hline KBM & 1175.61 & 1065.77 & 109.85 & 0.80 & 10.31 \\
\hline Radius & 1175.61 & 1017.80 & 157.81 & $2.14^{* *}$ & 15.51 \\
\hline Matching algorithm & Fertilizers users $(n=103)$ & $\begin{array}{l}\text { Both rice variety and } \\
\text { fertilizers users }(n=249)\end{array}$ & ATT & $t$-value & Change (\%) \\
\hline NNM & 1175.61 & 1481.20 & -305.59 & $-2.30^{* *}$ & -20.63 \\
\hline KBM & 1175.61 & 1484.87 & -309.25 & $-2.83^{* * *}$ & -20.83 \\
\hline Radius & 1175.61 & 1599.74 & -424.13 & $-5.73^{* * *}$ & -26.51 \\
\hline
\end{tabular}

ATT, Average Treatment Effect on the Treated, ${ }^{* * *}$ and ${ }^{* * *}$ are significant at 10,5 and $1 \%$ levels, respectively

\section{Abbreviations}

ATT: Average Treatment Effect on Treated; BFG: Bourguignon, Fournier, and Gurgand; CRI: Crops Research Institutions; DFID: Department for International Development; ESR: Endogenous Switching Regression; FASDEP: Food and Agriculture Sector Development Policy; GHç: Ghana cedis; GDP: Gross Domestic Product; LATE: Local Average Treatment Effect; MoFA: Ministry of Food and Agriculture; MNP: Multinomial Probit; NDPC: National Development Planning Commission; NERICA: New Rice for Africa; OLS: Ordinary least squares; PSM: Propensity Score Matching; SDG: Sustainable Development Goal; SARI: Savanna Agricultural Research Institute; TLU: Tropical Livestock Units.

\section{Acknowledgements}

The authors gratefully acknowledge the two anonymous referees and the editor for their insightful and valuable comments which helped improve the earlier version of this paper. That notwithstanding, the usual disclaimer applies.

\section{Authors' contributions}

MA: funding acquisition, conceptualization, literature review, methodology, investigation, writing —original draft preparation. KO-Y: supervision, validation, writing - reviewing and editing. PPA: literature review, data collection, writing — reviewing and editing. CAW: methodology, econometric analysis, writing - reviewing and editing. All authors read and approved the final manuscript.

\section{Authors information}

Monica Addison (PhD) is a Research Fellow at BIRD, KNUST, Ghana. Monica is a gender expert who believes that gender inequality is a driver and outcome of persistent poverty, therefore, development efforts should promote inclusive development for all - men, women, youth, aged and physically challenged. She has worked on different research projects and specialized in gender and agricultural technology. Monica conducts applied economics research (both qualitative and quantitative), embarks on community engagement activities and teaches and mentors students at KNUST. She has published Nine (9) papers in peer-reviewed journals, one (1) book chapter, one (1) paper in conference proceedings and participated in several international conferences to present paper on gender related topics.

Kwasi Ohene-Yankyera (PhD) has been a senior faculty at the Department of Agricultural Economics, Agribusiness and Extension of the KNUST, Ghana for over 30 years. He has about 50 publications/articles/ reports that have been used to explore a number of policy issues in agricultural development. He has consulted for the World Bank/IBRD, the Reseau-Netherlands, the Ricercae 
Cooperazione (Italian NGO), the Federal Department of Agriculture and Rural Development (Nigeria), the N2 Africa Project, the International Institute of Tropical Agriculture (IITA-Nigeria), and recently led a research team for DanidaGhana Pilot Research Street Foods Project and for the Overseas Development Association (ODA-UK)

Dr. (Mrs.) Patricia Pinamang Acheampong is a Senior Research Scientist with the CSIR-Crops Research Institute. She is an agricultural economist with specialized interest in agricultural policy, gender-related issues in agriculture and production economics. She is specifically interested in structural change (from subsistence agriculture to commercial agriculture) for livelihood development of smallholder farmers. She has much experience in agricultural marketing, teaching farmer groups and other stakeholders about agricultural marketing dynamics. She has published about twenty-six (26) papers in peer-reviewed journals, serves as reviewer for selected journals and participated in several international conferences.

Dr. Camillus Abawiera Wongnaa is an Agricultural Economist and a Senior Lecturer at the Department of agricultural economics Agribusiness and Extension of the Kwame Nkrumah University of Science and Technology, KNUST, Kumasi-Ghana. Dr. Wongnaa possesses excellent research skills and has mentored many students to undertake research at both the undergraduate and postgraduate levels. He has authored about thirty (30) refereed journal articles, two (2) book chapters and participated in several international conferences in the areas of agricultural economics and entrepreneurship. His research areas are production economics, productivity and efficiency analysis, food security, rural livelihood, climate change and agriculture.

\section{Funding}

This work was supported by the Africa Rice Centre (AfricaRice), through financial support from African Development Bank (AfDB) (Grant Number 2100155022217) funded project dubbed "Sustainable Agricultural Research for Development of Strategic Crops in Africa (SARD-SC)."

\section{Availability of data and materials}

It is possible to access the data upon personal request from the principal investigator.

\section{Declarations}

\section{Ethics approval and consent to participate}

Not applicable.

\section{Consent for publication}

We, the authors, have seen and approved the final version of the manuscript being submitted. We declare that the article is the authors' original work, has not received prior publication and is not under consideration for publication elsewhere.

\section{Competing interests}

The authors declare that they have no conflict of interest.

\section{Author details}

${ }^{1}$ Bureau of Integrated Rural Development (BIRD), Kwame Nkrumah University of Science and Technology (KNUST), Kumasi, Ghana. ${ }^{2}$ Department of Agricultural Economics, Agribusiness and Extension, Kwame Nkrumah University of Science and Technology (KNUST), Kumasi, Ghana. ${ }^{3}$ Socioeconomics Section, Council for Scientific and Industrial Research-Crops Research Institute, Kumasi, Ghana.

Received: 19 March 2021 Accepted: 13 September 2021

Published online: 14 January 2022

\section{References}

1. World Bank Group. Third Ghana Economic Update: Agriculture as an Engine of Growth and Jobs Creation. Washington, D.C; 2018.

2. Ministry of Food and Agriculture (MoFA). Planting for Food and Jobs, Strategic Plan for Implementation from 2017-2020, Republic of Ghana; 2017
3. Ministry of Food and Agriculture (MoFA). National Rice Development Strategy (NRDS). Republic of Ghana: MOFA, Accra; 2019.

4. Damba OT, Ansah IGK, Donkoh SA, Alhassan A, Mullins GR, Yussif K, Taylor MS, Tetteh BKD, Appiah-Twumasi M. Effects of technology dissemination approaches on agricultural technology uptake and utilization in Northern Ghana. Tech Society. 2020;62:101294.

5. Asante EG, Appiah MR, Ofori-Frimpong K, Afrifa AA. The economics of fertilizer use on some peasant cocoa farms in Ghana. Ghana J Agric Sci. 2004:33:183-90.

6. Nin A, Arndt C, Precktel P. Is agricultural productivity in developing countries really shrinking? New evidence using a modified nonparametric approach. J Dev Econ. 2003;71:395-415.

7. World Development report. Agriculture for development. Washington, D.C: World Bank; 2008.

8. Diagne A, Adekambi SA, Simtowe FP, Biaou G. The impact of agricultural technology adoption on poverty: the case of NERICA rice varieties in Benin. Paper contributed to the 27th Conference of the International Association of Agricultural Economists, August 16-22, 2009; Beijing, China; 2009.

9. Nin-Pratt A, Johnson M, Magalhaes E, Diao LX, Chamberlin J. Priorities for realizing the potential to increase agricultural productivity and growth in Western and Central Africa. IFPRI Discussion Paper 00876. International Food Policy Research Institute. Washington, DC; 2009.

10. Anang BT, Bäckman S, Sipiläinen T. Technical efficiency and its determinants in smallholder rice producers in Northern Ghana. J Dev Areas. 2016;50(2):311-28. https://doi.org/10.1353/jda.2016.0072.

11. Osei-Asare Y. Mapping of Poverty Reduction Strategies and Policies (PRSPs) related to Rice Development in Ghana. Coalition for African Rice Development (CARD). Nairobi, Kenya; 2010.

12. Amanor-Boadu V. Rice Price Trends in Ghana (2006-2011). Monitoring, evaluation and technical support services (METSS). Ghana Research and Issue Paper Series No. 02-2012. Accra, Ghana; 2012.

13. Wordofa MG, Hassen JY, Endris GS, Aweke CS, Moges DK, Rorisa DT. Adoption of improved agricultural technology and its impact on household income: a propensity score matching estimation in Eastern Ethiopia. Agric Food Secur. 2021;10(5):1-12.

14. Jambo Y, Alemu A, Tasew W. Impact of small-scale irrigation on household food security: evidence from Ethiopia. Agric Food Secur. 2021;10(21):1-16

15. Cunguara B, Darnhofer I. Assessing the impact of improved agricultural technologies on household income in rural Mozambique. Food Policy. 2011:36(3):378-90.

16. Kassie M, Shiferaw B, Muricho G. Agricultural technology, crop income, and poverty alleviation in Uganda. World Dev. 2011;39(10):1784-95.

17. Evenson R, Gollin D. Assessing the impact of the green revolution: 1960 to 2000. Science. 2003;300(2):758-62.

18. Wiredu AN, Zeller M, Diagne A. What determines adoption of fertilizers among rice-producing households in Northern Ghana? Q J Int Agric. 2015:54(3):263-83.

19. Awotide BA, Awoyemi TT, Diagne A. Access to certified, improved rice seed and farmers' income in Nigeria. J Crop Improv. 2012;26(4):558-79.

20. Minten B, Barrett CB. Agricultural technology, productivity, and poverty in Madagascar. World Dev. 2008;36(5):797-822

21. Dearden P, Allison G, Carter M, Daniel P, Jones S, Kowalski B, Lowe J, Roland R, Surridge M, Jones STS. The Contributors CIDT Staff of the Centre for International Development and Training provide call-down training and facilitation services to DFID on Project and Programme Management; 2003

22. Kijima Y, Otsuka K, Sserunkuuma D. Assessing the impact of NERICA on income and poverty in central and western Uganda. Agric Econ. 2008;38:327-37.

23. Ding S, Meriluoto L, Reed WR, Tao D, Wu H. The impact of agricultural technology adoption on income inequality in rural China: evidence from southern Yunnan Province. China Econ Rev. 2011;22:344-56.

24. Easterly WR. The lost decades: developing countries stagnation in spite of policy reform 1980-1998. J Econ Growth. 2001;6(2):135-57.

25. Rajan R, Subramanian A. Aid and growth: what does the cross- country evidence really show? IMF Working Paper; WP/05/127; 2005. 
26. Chamberlin J. Defining smallholder agriculture in Ghana: Who are smallholders, what do they do and how are they linked with markets? GSSP Background Paper no. 6. Washington, DC: IFPRI; 2007.

27. Ragasa C, Dankyi A, Acheampong P, Wiredu AN, Chapato A, Asamoah M, Tripp R. Patterns of adoption of improved rice technologies in Ghana. Working paper 35. International Food Policy Research Institute (IFPRI). Washington, D.C.; 2013.

28. Schneider UA, Havlik P, Schmid E, Valin H, Mosnier A, Obersteiner M, Bottcher H, Skalsky R, Balkovic J, Sauer T, Fritz S. Impacts of population growth, economic development, and technical change on global food production and consumption. Agric Syst. 2011;104(2):204-15.

29. Bekele W, Drake L. Soil and water conservation decision behavior of subsistence farmers in the Eastern Highlands of Ethiopia: a case study of the Hunde-Lafto area. Ecol Econ. 2003;46(3):437-51.

30. Kolawole $\mathrm{O}$. Determinants of profit efficiency among small scale rice farmers in Nigeria. Res J Appl Sci. 2006;1(1-4):116-22.

31. Edeoghon C, Ajayi MT, Ugboya T. Awareness and use of sustainable agricultural practices by arable crop farmers in Ikpoba Okha local government area of Edo State. Sustain Dev Agric Environ. 2008;3(2):55-63.

32. Moser CM, Barrett CB. The disappointing adoption dynamics of a yieldincreasing, low external-input technology: the case of SRI in Madagascar. Agric Syst. 2003;76(3):1085-100.

33. Monfared N. Adoption and consequences of technologies on rural women in south and North of Iran. Afr J Agric Res. 2011;6(14):3382-7.

34. Mendola M. Agricultural technology adoption and poverty reduction: a propensity-score matching analysis for rural Bangladesh. Food Policy. 2007:32(3):372-93.

35. Uaiene RN, Arndt C. Farm household efficiency in Mozambique. Paper contributed to the 27th Conference of the International Association of Agricultural Economists, August 16-22, 2009, Beijing, China; 2009.

36. Ma W, Abdulai A. Linking apple farmers to markets: determinants and impacts of marketing contracts in China. China Agric Econ Rev. 2016:8(1):2-21.

37. Khanal AR, Mishra AK. Agritourism and off-farm work: survival strategies for small farms". Agric Econ. 2014;45(1):65-76.

38. Bourguignon F, Fournier M, Gurgand M. Selection bias corrections based on the multinomial logit model: Monte Carlo comparisons. J Econ Surv. 2007:21(1):174-205

39. Park T, Mishra AK, Wozniak SJ. Do farm operators benefit from direct to consumer marketing strategies? Agric Econ. 2013;45(2):213-24.

40. Dehejia RH, Wahba S. Propensity score matching methods for non-experimental causal studies. Rev Econ Stat. 2002:84(1):151-61.

41. Lokshin M, Sajaia Z. Maximum likelihood estimation of endogenous switching regression models. Stand Genomic Sci. 2004:4(3):282-9.

42. Buchan I. Calculating the Gini coefficient of inequality. Northwest Institute for Bio Health Informatics. UK, Manchester; 2002.

43. Greene WH. Econometric analysis. 5th ed. New: Prentice Hall; 2003.

44. Gujarati DN. Basic econometrics. United States Military Academy, West Point. Published by McGraw-Hill//rwin, a business unit of The McGraw-Hili Companies, Inc. 1221 Avenue of the Americas, New York, 10020; 2003.
45. Santeramo FG, Goodwin BK, Adinolfi F, Capitanio F. Farmer participation, entry and exit decisions in the Italian Crop Insurance Program. J Agric Econ. 2016:67(3):639-57.

46. Addison M, Ohene-Yankyera K, Aidoo R. Gender effect on adoption of selected improved rice technologies in Ghana. J Agric Sci. 2018;10(7):390-402

47. Leake $G$, Adam B. Factors determining allocation of land for improved wheat variety by smallholder farmers of northern Ethiopia. J Dev Agric Econ. 2015;7(3):105-12. https://doi.org/10.5897/jdae2014.0621.

48. Teklewold H, Adam RI, Marenya P. What explains the gender differences in the adoption of multiple maize varieties? Empirical evidence from Uganda and Tanzania. World Dev Perspect. 2020;18:100206.

49. Cerdan-Infantes P, Maffioli A, Ubfal D. Improving technology adoption in agriculture through extension services: evidence from Uruguay. Working Paper: OVE/WP-04/09. Inter- Office of Evaluation and Oversight, OVE, American Development Bank, Washington, D.C. 2009.

50. Abdulai A, Huffman W. The adoption and impact of soil and water conservation technology: an endogenous switching regression application. Land Econ. 2014;90(1):26-43.

51. Binswanger HP, Klaus D, Gershon F. Power, distortions, revolt and reform in agricultural land relations. In: Jere RB, Srinivasan TN. Handbook of development economics, vol 3, ed. Amsterdam: Elsevier Science; 1995.

52. Chen Z, Huffman WE, Rozelle S. Inverse relationship between productivity and farm size: the case of China. Contemp Econ Policy. 2011;29(4):580-92.

53. Grainger A, Francisco HA, Tiraswat P. The impact of changes in agricultural technology on long-term trends in deforestation. Land Use Policy. 2003:20(3):209-23.

54. Asfaw S, Shiferaw B, Simtowe F, Haile MG. Agricultural technology adoption, seed access constraints and commercialization in Ethiopia. J Dev Agric Econ. 2011;3(9):436-47.

55. Babatunde RO, Qaim M. Impact of off-farm income on food security and nutrition in Nigeria. Food Policy. 2010;35:303-11.

56. Nata JT, Mjelde JW, Boadu FO. Household adoption of soil-improving practices and food insecurity in Ghana. Agric Food Secur. 2014;3(1):17.

57. Jahnke HE. Livestock production systems in livestock development in tropical Africa. Kiel, FRG: Kieler Wissenschaftsverlag Vauk; 1982.

58. Runge-Metzger A. Decision calculi smallholder operation-households in relation to cost-effectiveness and acceptability of selected agricultural innovation — study in the Upper Regions of Ghana. Wissenschaftsverlag Vauk, Kiel, Germany; 1991.

\section{Publisher's Note}

Springer Nature remains neutral with regard to jurisdictional claims in published maps and institutional affiliations.

Ready to submit your research? Choose BMC and benefit from

- fast, convenient online submission

- thorough peer review by experienced researchers in your field

- rapid publication on acceptance

- support for research data, including large and complex data types

- gold Open Access which fosters wider collaboration and increased citations

- maximum visibility for your research: over 100M website views per year

At BMC, research is always in progress.

Learn more biomedcentral.com/submissions 